\title{
Trends in international student mobility: the case of France
}

\section{Silivanova}

\author{
Postgraduate student, teacher at The Department of Indo-European Languages, The National University of Ostroh Academy, Ostroh, \\ Ukraine \\ Corresponding author. E-mail: silivanova.ilona@gmail.com
}

Paper received 08.10.18; Accepted for publication 15.10.18.

\author{
https://doi.org/10.31174/SEND-PP2018-180VI74-11
}

\begin{abstract}
International student mobility is becoming an integral part of many higher education establishments around the world and France is no exception. The aim of this research report is to provide a thorough understanding of the trends related to international student mobility in France. The article provides an overview of international student mobility in the context of major policy reforms as well as gives an indepth analysis of international enrollment trends in France with a focus on emerging practices in recruitment and selection.
\end{abstract}

Keywords: international student mobility, academic mobility, trends, international student, higher education, France.

Academic mobility is a growing phenomenon in the contemporary world, which has received increased attention both in terms of policy and research over the last decade. International student mobility of the 21 st century is largely impacted and shaped by globalization, internationalization and Europeanisation of tertiary education $[0$, p. 10]. Higher education responds to challenges of Europeanisation, internationalization and globalization by introducing newer forms of mobility, internasionalisation of curricula, opening of branch offices, signature of the mutual recognition agreements between universities, improvement of quality assurance and evaluation $[0$, p. 46]. All the above-mentioned trends can be easily traced in higher education policies in Europe, and in particular, France.

Academic mobility in the context of Europeanization, internationalization and globalization of higher education was considered by a number of French and foreign researchers, such as N. Stromquist (2002), U. Teichler (2003), M. Kelo (2006), J. Knight (2007), V. Naidoo (2006), N. Varghese (2008), etc [0, p. 257]. Different national reports regarding international students in France were carried out in order to analyse the implementation of Bologna reforms, to make suggestions and to develop strategies for the increase of academic mobility in France. Among them Patrick Weil's report in 1997, Albert Prévos', Bernard Dufourg's, Alain Claeys' reports in 1999, Eric Flitti's report in 2000 and Elie Cohen in 2001 which encourage the French government to simplify visa application procedure and selection criteria to participate in mobility programs, to adopt the charter advocating international students' rights and finally to organize international student support services [0, p. 31].

France is the country with an excellent academic reputation and is the fourth most popular study destination in the world. International students continue their upward path in French universities and already reached 325000 in 2017/2018. However, the latest statistics from Campus France show that while the total number of international students in France grow, the French market share has dropped from $9,3 \%$ in 2005 to $6,7 \%$ in 2015 [0, p. 30]. While the UN predicts a global stagnation of the international flow of mobile students by 2025, there is a clear need to reaffirm the attractiveness of France on the global mobility market. Hence, the aim of the article is to look at the current and future trends related to international student mobility in France.

Pierre Buhler, a former French diplomate, an associate professor at Sciences Po, Paris in his report entitled «Proposals for the university mobility policy» states that since 1998 numerous articles devoted to the topic of incoming student mobility express the growing discontent over the government's efforts to make France more attractive for international students. Such complaints if to say so, can be grouped into three categories: quality of reception, absence of competitive selection for international students and scholarship policies.

The problems raised by Pierre Buhler, encouraged the Government of the French Republic to begin the process of strategic planning in higher education and the search of new directions for the international activities of French universities. Moreover, the formation of priority areas of international academic mobility in France was also influenced by the following global trends: - the massification of higher education; $\bullet$ the formation of knowledge society based on lifelong learning; $\bullet$ the diversity of the society needs, and accordingly, the diverse requirements for the content, volume, forms and methods of teaching in the higher education system; - demographic decline (increasing proportions of elderly compared with the proportion of the student population and, as a consequence, the necessity to take into account the needs of older age groups in educational policy; • high migration rates of skilled labour («brain drain»).

Thus, the above-mentioned factors helped to identify three interrelated trends in international academic mobility in France: 1. the increase in the number of international students; 2. the creation of education hubs for international and French mobile students; 3 . the introduction of a new financing model.

To respond effectively to these trends the government of France has identified the main vectors of state policy in the field of international education for the nearest future, namely: sustainability and increasing accessibility to higher education; quality assurance in tertiary education; long-term financial efficiency in the higher education sector.

A significant increase in the number of international mobile students can undoubtedly be achieved by simplified procedures for obtaining a residence permit. According to research director at the CNRS and a member of the AixMarseille University García-Peñalosa Cecilia and Professor at Sciences Po's Department of Economics Wasmer Étienne, the application for a long-term visa must be processed along with the application for a temporary residence permit. These changes have already begun to take place. The Law on the Rights of Foreigners in France of March 7, 2016 simplifies the administrative procedures for issuing a temporary residence permit for students. From January 1, 2017 foreign nationals no longer have to submit a medical certificate issued by the French Office for Immigration and Integration (OFII) in support of their application for a residence 
permit [0]. What is more, students who have already resided in France for at least 12 months have the opportunity to obtain a residence permit with the duration which would correspond to the length of a student's course of study (for a period from 2 to 4 years). Previously, foreign students with a long-term visa were required to annually confirm their right to stay in France's local authorities (Préfecture) and the OFII.

Access to work certainly influences the image and the attractiveness of France on the international scale. From the point of view of mobile students, work option is a major factor affecting destination choice. France's Labor rules allows students, irrespective of their year of study, to work part-time or even full-time on the condition that the total number of working hours per year does not exceed 964 hours. In spite of this advantage, there is an urgent need to introduce labor innovations, namely simplify the procedure for obtaining work permits. Moreover, electronic submission of the work permit application would become a real innovation especially in major university towns [0, p. 207]. In order to avoid misuse of the student visa for the purpose of employment, the Department for employment of foreign nationals under the French Ministry of Labor should have the right to refuse the renewal of a temporary work permit is case of students' poor academic performance. Following the example of Belgium, an additional measure should also be a consistency check of the students' studying and working schedules.

The intensive orientation of French universities to mobility organized under Cooperation and Bilateral Agreements signed with higher education institutions abroad can also be the guarantee of a gradual increase in the number of inbound internationally mobile students. Such conventions are the most effective means of assuring the level of student knowledge and his/her academic achievements. Furthermore, the agreements guarantee the existence of student's career plan and condition the return of those who are not invited to work in France to their country of origin, especially in the context of development assistance policies. On the contrary, if the mobility is individual it is the responsibility of International Relations Office to check the students' academic performance as well as the existence of career plan which matches France's labour market needs [0, p. 206].

A boost in the attractiveness of scientific and technical activities as well as creation of favorable conditions for research and innovation are essential prerequisites for the development of student mobility in France. A sharp decline in the number of internationally mobile students in academic science has become a commonplace phenomenon over the last few years. According to Doctor of Economics, lecturer at the University of Paris-XI and co-author of the report "Students and Researchers in 2020: Goals of International Mobility and Attractiveness" Mohamed Harfi, it is possible to restore previous popularity by introducing educational innovations in the university curriculum, namely mentoring system [0, p. 202]. The purpose of mentoring is to accelerate the process of freshers' adaptation, improve their learning and further educational possibilities.

An increase in the number of inbound internationally mobile students of technical specialties and, consequently, the growth in number of foreign scientific and technical personnel in the labor market may also be due to the weakening of selection criteria. According to Claude Mathieu, co-author of the report "Students and Researchers in 2020: Goals of International Mobility and Attractiveness", the level of proficien- cy in a foreign language should not be the main selection criterion for students willing to study scientific and technical disciplines: "If B2-level certificate is a prerequisite to study social-humanitarian disciplines, then such a criterion should not be key for the students at the departments of science and technology." After all, the fluency in French can be the result of their academic mobility to France [0, p. 206]. The additional step taken in this direction should concern informing students about employment opportunities in the domain of science and technology after graduation. Creation of the alumni associations for internationally mobile students that complete their master's or doctoral degrees in particular French university can help achieve this objective. Such alumni associations can compete for an educational subvention by offering projects. The projects can deal with information and communication technologies [0, p. 203].

According to Jane Knight, professor at the Ontario Institute for Studies in Education at the University of Toronto, states that formation and development of international educational hubs is the key trend in international higher education in recent years. Educational hubs signify the move of transnational education beyond its borders, with a new emphasis on research, knowledge and innovation [0, p. 39]. In her view, the transformation of the country, in particular France, into the international educational hub, is preceded by the systematic work to unite the efforts of many local and foreign actors, namely universities, students, research centers and specialists in the development of education and the knowledge industry [0, p. 28].

The main reason for the formation of hubs in France is a rapid decrease in the total score of the national higher education institutions in the world ranking, in particular, Shanghai rating. In order to improve its international standing, in 2015 the French government invested 7.5 billion euros in the University of Paris-Saclay, with the aim to turn it into a leading continental university. The University of Paris-Saclay has already united 19 universities in France and offers around 190 international masters degrees for the internationally mobile students under the age of 30 . If to follow its strategic development plan, the university will unite 10, 000 scientists and 70, 000 students by 2025 [0, p. 12].

The desire of the French government to turn the University of Paris-Saclay into Student Education Hub is explained not only by the need to improve the position of higher education institutions in the ranking. An explanation of the reasons was made in Jane Knight's book "International Education Hubs: Student, Talent, Knowledge-Innovation Models". Possibility to increase economic indicators, improve the quality of education, attract the top-quality skilled workers, ameliorate geopolitical status, become the center for scientific and educational innovation predominate among the prerequisites for the creation of educational hubs [0]. Knight emphasizes that there is no one-size-fits-all approach to creating an education hub, therefore, the needs of a given country should be taken into account $[0$, p. 91$]$. However, it will take time to verify whether the education hubs become initiatives with strategic goals and real investment that will enhance the reputation of the country, its competitiveness and geopolitical status in the region and beyond, or just a short-lived trend [0, p. 39].

Another trend in the international academic mobility of students without which it is impossible to explain further educational development in France is introduction of a new higher education funding model. According to French schol- 
ars Cecilia García-Peñalosa and Étienne Wasmer, French universities can become more accessible and enhance their prestige on the international level by increasing financial efficiency in the field of higher education. In the short term, the registration fee for non-EU students may be set by the university in accordance with the quality of educational services offered.

The main peculiarity of French university financing is that it was and remains almost entirely government-funded. Each year, the government of France spends an average of 10,000 euros per student. However, the student must pay the admission fee, which is fixed by the French Ministry of Higher Education. Thus, in the academic year 2017/18, the enrollment fee at the license level is 184 euros, master's level - 256 euros and doctorate's level - 391 euros. However, at private universities, the tuition fee is usually significantly higher. In general, according to the OECD Education Indicators 2014, France's spending on tertiary education amounts to more than $6 \%$ of GDP in a country where the share of private funding does not exceed $20 \%$ (as opposed to $30 \%$ in OECD countries and $62 \%$ in the USA) Consequently, taking into account the fact that national and international students pay the same one-time payment, the Government of France finances the education of individuals who in no way contribute to its state growth [0, p. 1-6], [1].

One possible solution to this problem could be the creation of a European-based compensation system for the country that serves as an educational services provider. If countries enter into the bilateral cooperation in the field of higher education, it should be agreed that under the terms the country importing education services must pay a fixed fee to the country exporting these services. As a result, $75 \%$ of the costs spent by the French government will be covered by the country importing mobile youth. Such reimbursement system can be considered fair as it encourages countries to attract international students while creating good admission conditions. At the same time, the reorientation of European countries' budgets towards investment in human capital does not exclude the possibility of privately funded universities $[0$, p. 9].
As for non-EU international students, on the example of the UK, France should suspend funding their studies. Tuition fees paid by non-EU international students can be used by the university to improve the quality of teaching and admission conditions of international students, thereby enhancing its attractiveness. Moreover, this money can be used to fund highly qualified and motivated international students from outside the EU. The implementation of such a policy does not mean that non-European students will receive a different education. Its goal is international students' full participation in existing programs and reduction of the tax burden in France [0, p.11].

The material presented in this article allows us to state that international academic mobility is a growing phenomenon, which incites both government and higher education institutions to modify their recruitment strategies to attract more internationally mobile students. To remain competitive on the global scale the Government of France has already started to introduce less strict changes to the laws governing residence and work permits. As for French universities, their priority tasks are introduction of mentoring system, creation of the alumni associations for former mobile students, weakening of selection criteria for students willing to study scientific and technical disciplines, orientation on student mobility organised within the framework of bilateral agreements.

The formation and development of international educational hubs is also among the key trends that will accompany international academic mobility in future. The University of Paris-Saclay, which is considered to be the first educational hub in France, is aimed at increase of economic indicators, improvement in the quality of education, attraction of the top-quality skilled workers and international students to France.

The launch of a new financing model is the last trend analysed in the article. With the aim to reduce tax burden on the residents and attract more self-funded students we might observe the introduction of tuition fees for non-EU students in France in the nearest future. But some unintended consequences that can result from its implementation still need to be well studied.

\section{REFERENCES}

1. Campus France. Chiffres-Clés, avril 2018. Retrieved 25 September 2018 from URL http://adem.public.lu/fr/publications/adem/2018/Chiffres-clesavril-2018/Chiffres-Cles-ADEM-Avril-2018.pdf

2. Coulon Alain, Paivandi Saeed. Les étudiants étrangers en France: l'état des savoirs. Rapport pour L'Observatoire de la Vie Étudiante, mars 2003. 52 p.

3. Dima, M.A. Handbook on Research on Trends in European Higher Education. Convergence, Editor, Editura IGI Global, USA, 2014. 516 pages.

4. García-Peñalosa C., Wasmer É. Préparer la france à la mobilité internationale croissante des talents // Note du conseil d'analyse économique, 2016. - N 31. P. 1-12.

5. Harfi Mohamed, Mathieu Claude Etudiants et chercheurs à l'horizon 2020: Enjeux de la mobilité internationale et de l'attractivité de la France. Paris, Commissariat général du plan, Septembre 2005. 249 pages.

6. International Trends in Higher Education 2015. University of Oxford, 2015. 25 pages.

7. Karl Waheed Advocates. The implementation of the law of 7 March 2016 on the rights of foreigners in France. Circulars of 2 November 2016. Retrieved 25 September 2018 from URL: https://karlwaheed.fr/en/the-implementation-of-the-law-of-7march-2016-on-the-rights-of-foreigners-in-france-circulars-of-2-

november-2016-provisions-applicable-as-of-1-november-2016and-1-january-2017/

8. Knight, Jane. Higher education in turmoil : the changing world of internationalization. Rotterdam : Sense Publishers, 2008. 241 pages.

9. Knight, Jane. International education hubs: student, talent, knowledge-innovation models. Dordrecht, Springer, 2014, 251 pp.

10. Laura M. Portnoi , Sylvia S. Bagley. Critical Perspectives on Global Competition in Higher Education: New Directions for Higher Education, Number 168. Jossey-Bass, Dec 2014. 112 p.

11. Mok, K. H., \& Yu, K. M. (Eds.). (2014). Internationalization of higher education in East Asia: Trends of student mobility and impact on education governance. New York: Routledge, 2014. 251 pages.

12. Sakhieva, R. G., Semenova, L. V., Muskhanova, I. V., Yakhyaeva, A. Kh., Iskhakova, R. R., Makarova, E. V. \& Shafigullina, L. Sh.. Academic mobility of high school students: concept, principles, structural components and stages of implementation. Journal of Sustainable Development, 8 (3), 2015. p. 256-262.

13. Teichler, Ulrich. International Student Mobility in Europe in the Context of the Bologna Process. Journal of International Education and Leadership, volume 2, issue1, Spring 2012. 13 pages 